\title{
Implementation of Practical Worksheet based on Multiple Representations with Basic Science Process Skills Indicators
}

\author{
Resi Pratiwi $^{1}$, Endang Susilaningsih ${ }^{2}$, Sri Susilogati Sumarti $^{3}$, Woro Sumarni ${ }^{4}$ \\ ${ }^{1}$ Graduate School, Universitas Negeri Semarang, Indonesia \\ ${ }^{2,3,4}$ Department of Chemistry, Faculty of Mathematics and Natural Sciences, Universitas Negeri Semarang, \\ Indonesia \\ ${ }^{1}$ Corresponding email: tiwi183club@gmail.com
}

\begin{abstract}
Practical worksheets can be used as a supporting tool in practicum activities. This worksheet is expected to help students transfer abstract knowledge to be more concrete. Practical worksheets based on multiple representations equipped with basic science process skills indicators applied to solubility practicum and solubility results. This study aimed to determine the effect of practical worksheets on basic science process skills. This practical worksheet contained material and practicum guides equipped with multiple levels of representation and indicators of basic science process skills. Before being applied to practicum activities, practical worksheets were validated in advance by material experts. Validation results stated that the practical worksheet was feasible and valid to be used in practicum activities. During the practicum, observers observed the students' basic science process skills through observation sheets. The results of observations on practicum activities showed students' basic science process skills included high criteria with 79\% and $77 \%$ completeness. These results showed that the application of practical worksheets based on multiple representations equipped with indicators of basic science process skills in solubility practicum and solubility times affect the basic science process skills.
\end{abstract}

Keywords: practical worksheet, multiple representations, basic science process skills,

\section{Introduction}

Practicum is a means for students to recognize equipment, materials, and chemical reactions. On this activity, things that are originally considered abstract become more real, so students could understand chemical concepts more deeply. Practicum activities in the laboratory are able to hone the three domains of student intelligence, namely cognitive, affective and psychomotor (Handayani et al., 2017). Practicum-based learning is more interesting. It increases learning interest and helps to understand the concepts taught (Baeti et al., 2014). The results of a field study conducted by Susiwi et al. (2009) state that chemistry learning in high schools rarely does lab work. Practicum activities in the learning process have basically been carried out in several schools, but are still limited to observation and verification of concepts or principles that have been studied. Practicum conducted in general, has not given students the opportunity to actively participate in the experiment. Students cannot understand the purpose of the practicum they are doing. This is not in accordance with the characteristics of chemistry as a process, especially students become less motivated to do practical activities. Laboratory activities should assist students in developing practical skills, students must also have direct experience with the concept of knowledge and obtain scientific skills with planning, designing, determining hypotheses, implementing and interpreting their own experiments, one of which is through inquiry (Chairam \& Nutsuda, 2015).

Practical worksheets can be used as one of the supporting tools in practicum activities. This worksheet is expected to help students transfer abstract knowledge to be more concrete. Based on the results of a survey conducted by the Khasanah (2017), several of practicum manuals, both integrated with textbooks circulating in high school / Islamic High School (MA) schools show that the practical worksheets integrated with textbooks have not used the scientific approach syntax. They circulate only in the form of a cookbook. The cookbook-shaped practical worksheets are indeed easy to implement by students but have weaknesses such as too guiding students when students carry out practical activities in the laboratory. This results in teachers tend to force students to understand concepts in learning so that students cannot express their opinions significantly and cannot develop thinking skills (Dwiyanti \& Siswaningsih, 2015). 
Practical worksheets are expected to make students better understand the practicum.

The practical worksheet used is multiple representation worksheet based on indicators of basic science process skills in solubility practicum and solubility product. This practical worksheet is not only a practical guide but also links the three levels of representation, namely macroscopic, submicroscopic and symbolic. This is because the process of learning chemistry in schools specifically on solubility and solubility product tend to still use conceptual teaching methods at the macroscopic and symbolic level. This learning process has not linked the three levels of representation, namely macroscopic, submicroscopic and symbolic. Teachers often fail to connect levels of representation during the learning process and often ignore submicroscopic levels (Milenkovic et al., 2014).

This worksheet is also equipped with indicators of basic science process skills so that students are expected to have sufficient science process skills during practicum activities. Practical worksheets are prepared with the aim to (1) help students in practicing in the laboratory, (2) facilitate teachers in carrying out learning in the laboratory, and (3) as a guide for students in conducting practical work to be more directed. There are 8 indicators of basic science process skills contained in the practical worksheets, namely (1) observing, (2) classifying, (3) measuring, (4) communicating, (5) referencing, (6) predicting, (7) knowing relationships space and time and (8) recognizing the relationship of numbers.

The results of interviews conducted by researchers with students and teachers in SMAN 11 Semarang found that: (1) the solubility and the solubility product material were never practiced, (2) the assessment of basic science process skills was not carried out in the learning process, (3) there were no supporting books specifically for practicum activities. Yildirim et al. (2011) and Manik et al. (2015) argue that the use of worksheets helps students in understanding chemical equilibrium material and mastery of the concepts of solubility and solubility results. Based on the description, the researcher wanted to know the effect of the implementation of the practical worksheet based on multiple representations equipped with basic science process skills indicators on students' basic science process skills in solubility and solubility product practicum.

\section{Methods}

This research was conducted at State Senior High School (SMAN) 11 Semarang with the research subjects of the eleventh grade students majoring in Science in class 1, 2 and 3 in 2nd semester of the academic year of 2017/2018. Data collection method used in this study was observation method. The steps of the research were: (1) teachers give a practical worksheet based on multiple representations to students, (2) students conduct practicum activities in accordance with the instructions in the practical worksheet, (3) observers assess basic science process skills appears to students during practicum activities. Observations were made using an observation sheet that was adjusted to the indicators of basic science process skills being observed. Then, the observation results were analyzed to determine the completeness of students' learning outcomes. The completeness of student learning outcomes was seen based on the basic science process skills that arose. If the completeness of students reaches more than $65 \%$, then it can be said that the lab worksheet influences the learning process, especially to provide students with basic science process skills. This is consistent with research conducted by Astuti et al. (2011) that the guided inquiry-based practicum worksheet developed is said to be effective if after following the learning using guided inquiry-based practicum worksheet, students complete in classical or greater than $65 \%$ of the number of students in the class. Before practical worksheets were applied in the learning process, expert material validation was carried out to determine its feasibility. The practical worksheet was said to be feasible and valid if the average value of the validator was at least 3. The assessment of the observation results was analyzed by calculating the average rating of each observer and then calculating the overall average. Meanwhile, the achievement of the value of each observed aspect was calculated based on the following formula:

$$
\text { Value }=\frac{\text { obtained scores }}{\text { maksimum score }} \times 100
$$




\section{Results and Discussion}

Practical worksheets based on multiple representations are manuals in solubility practicum activities and solubility results. This worksheet was equipped with indicators of basic science process skills in each activity carried out by students. In addition, the contents in this worksheet also link three levels of multiple representations, namely macroscopic, submicroscopic and symbolic. There are indicators of science process skills and multiple levels of representation in worksheets so that students can hone basic science process skills during practicum activities and are able to understand solubility and solubility product material more deeply. Practical worksheets based on multiple representations were applied to practicum activities to find out how much influence they had on the learning process, especially during practicum activities.

That contain of basic science process skills indicatorsBefore being used in practicum activities, this lab worksheet was tested for feasibility first. The feasibility test for the lab worksheet was done by content validation by material experts. Based on the results of validation, the average value of the four validators was 3.4 , so the practical worksheet could be said to be feasible and valid to be used in solubility practicum and solubility results at SMAN 11 Semarang. Meanwhile, the recap of validation values are presented in Table 1 .

Table 1. Validation Average Value of Practical worksheet

\begin{tabular}{cc}
\hline Validator & $\begin{array}{c}\text { Validation Average } \\
\text { Value }\end{array}$ \\
\hline 1 & 3.65 \\
2 & 3.7 \\
3 & 3 \\
4 & 3.25 \\
Value & 3.4 \\
\hline
\end{tabular}

There were two types of practicum carried out by students, namely predicting sediment and the effect of similar ions. Both of these lab works were assessed by observers through observation sheets that were adjusted to indicators of basic science process skills. Completeness of student learning outcomes from practicum observations can be seen in Figure 3 . The completeness of the results of this observation was seen from the students' scores.

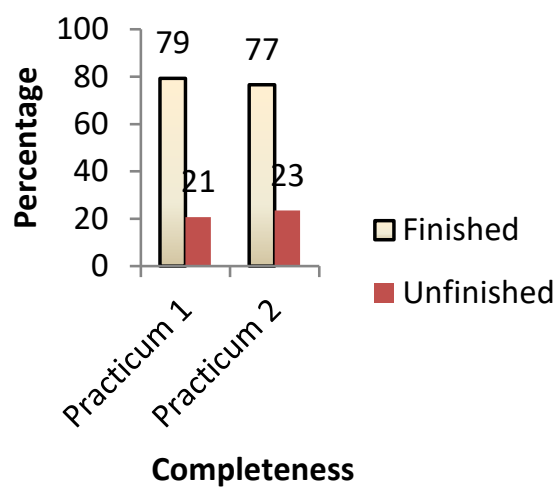

Figure 1. The Completeness of the Learning Outcomes of Basic Science Process Results of Observation

Figure 1 shows that the completeness of learning outcomes of students' basic science process skills observation results reached $79 \%$ for practicum 1 and $77 \%$ for practicum 2 . These results indicated that most students have met the minimum completeness criteria for basic science process skills. The expected minimum completeness was $65 \%$. Thus it could be said that the practical worksheets used had an effect on the students' basic science process skills so that the completeness of the observation results could be achieved. This is consistent with research conducted by Aminudin et al. (2015) and Anggraini et al. (2016) that multiple representation worksheets and science process skills are very well used to train students' basic science process skills. The science process skills of students will be higher if the involvement of students in practicum and other scientific activities is also higher. In addition, according to Rahayu's research (2011) the process skills approach which is research learning can increase students' potential in scientific processes and scientific attitudes.

This practical worksheet contains multiple levels of representation that were expected to make students better understand solubility material and solubility results, especially in practicum activities. As a result, the practicum done by students was not just a proof of concept, but also to develop skills, especially basic science process skills. Arifin et al. (2015) state that the learning of guided inquiry-based practicum with LKPS provides students with 
opportunities to actively participate in the learning process. Learning can increase students' curiosity and encourage students to be able to communicate their opinions so that the basic process skills of students are well honed. This is consistent with the results of interviews with teachers and students after using the practical worksheet. Students became more active and motivated in practicum activities. In the previous learning process, students rarely practiced, so the existence of practicum made learning more interesting and enjoyable. In addition, the practical worksheets used were very helpful in practicum activities. These worksheets did not only guide students in practicum activities but also made students understand practical activities from the macroscopic, submicroscopic and symbolic level. Good products are produced with good process skills. Students' learning outcomes can be improved if supported by teacher sensitivity in stimulating students' skills in overcoming existing weaknesses (Erina \& Kuswanto, 2015).

Broadly speaking, the practical worksheet based on multiple representations that equipped with basic science process skills indicators influenced the basic science process skills of students. Further, the results of this study could be used as a reference for teachers to be able to develop practical worksheets and implement them in the learning process or practicum activities for different materials and subjects. This can be done to make students be able develop skills, especially basic science process skills.

\section{Conclusion}

Based on the results and discussion, it can be concluded that the practical worksheets are based on multiple representations equipped with basic science process skills indicators suitable for use in practicum activities. Implementation of a multi-representation practical worksheet equipped with indicators of basic science process skills influences students' basic science process skills in practicum activities. This can be seen from the results of student learning completeness from observation practicum 1 and practicum 2 reaching $79 \%$ and $77 \%$.

\section{References}

Aminudin, M.A., Fadiawati, N., \& Tania, L. (2015). Pengembangan LKS Berbasis Multipel Representasi pada Materi Klasifikasi Materi. Jurnal Pendidikan dan Pembelajaran Kimia. 4(2), 720-731.

Anggraini, R., Wahyuni, S., \& Lesmono, A.D. (2016). Pengembangan Lembar kerja Siswa (LKS) Berbasis Keterampilan Proses di SMAN 4 Jember. Jurnal Pembelajaran Fisika. 4(4), 350-356.

Arifin, U.F., Hadisaputro, S., \& Susilaningsih, E. (2015). Pengembangan Lembar Kerja Praktikum Siswa Terintegrasi Guided Inquiry untuk Keterampilan Proses Sains. Chemistry in Education. 4(1), 54-60.

Astuti, W.P., Nur, M., \& Rahayu, Y.S. (2011). Pengembangan Perangkat Pembelajaran untuk Meningkatkan Hasil Belajar Siswa Melalui Pelatihan Strategi Belajar Membaca pada Pokok Bahasan Sistem Peredaran Darah di SMA. Pendidikan Sains Pascasarjana Universitas Negeri Surabaya. 1(1), 28-35.

Baeti, S.N., Binadja, A., \& Susilaningsih, E. (2014). Pembelajaran Berbasis Praktikum Bervisi SETS untuk Mrningkatkan Keterampilan Laboratorium dan Penguasaan Kompetensi. Jurnal Inovasi Pendidikan Kimia. 8(1), 1260-1270.

Chairam, S. \& Nutsuda, K. (2015). Exploring Secondary Students Understanding of Chemical Kinetics through Inquiry-Based Learning Activities. Eurasia Journal of Mathematics, Science, and Technology Education. 11(5), 937-956.

Dwiyanti, G. \& Siswaningsih, W. (2005). Keterampilan Proses Sains Siswa SMU Kelas II Pada Pembelajaran Kesetimbangan Kimia Melalui Metode Praktikum. Makalah. Seminar HISPIPAI Universitas Pendidikan Indonesia.

Erina, R. \& Kuswanto, H. (2015). Pengaruh Model Pembelajaran InsSTAD terhadap Keterampilan Proses Sains dan Hasil Belajar Kognitif Fisika di SMA. Jurnal Inovasi Pendidikan IPA. 1(2), 202-211.

Handayani, C.F., Sunarto, W., \& Sumarti, S.S. (2017). Penerapan Model Pembelajaran Guided Discovery Melalui Kegiatan Praktikum pada Materi Stoikiometri Larutan. Jurnal Inovasi Pendidikan Kimia. 11(1), 1840-1848. 
Khasanah, F. (2017). Desain lembar Kerja Praktikum Terpadu Soal Kognitif Berbasis Inkuiri Terbimbing untuk Meningkatkan Keterampilan Laboratorium dan Pengetahuan Siswa. Tesis. Semarang: Pascasarjana Unnes.

Manik, D.P., Ila, P., \& Lisa, T. (2015). Efektivitas Inkuiri Terbimbing pada Materi Kelarutan dan Ksp dalam Meningkatkan Penguasaan Konsep. Jurnal Pendidikan dan Pembelajaran Kimia. 4(2), 744-755.

Milenkovic, D.D., Segedinac, M.D., \& Hrin, T.N. (2014). Increasing High School Students' Chemistry Performance and Reducing Cognitive Load Through an Instructional Strategy Based on the Interaction of Multiple Levels of
Knowledge Representation. Journal of Chemical Education. 91(9), 1409-1416.

Rahayu, E. (2011). Pembelajaran Sains dengan Pendekatan Keterampilan Proses untuk meningkatkan Hasil Belajar dan kemampuan Berpikir Kreatif Siswa. Jurnal Pendidikan Fisika Indonesia. 7(1), 33-37.

Susiwi, Hinduan, A.A., Liliasari, \& Ahmad, S. (2009). Analisis Keterampilan Proses Sains Siswa SMA pada Model Pembelajaran Praktikum D-E-H. Jurnal pengajaran MIPA. 14(2), 87-104.

Yildirim, N., Sevil, K., \& Alipasa, A. (2011). The Effect of the Worksheets on Students Achievement in Chemical Equilibrium. Journal of Turkish Science Education. 8(3), 44-58. 